ISSN: 2362-1303 (Paper) | elSSN: 2362-1311(Online)

JOURNAL OF ADVANCED ACADEMIC RESEARCH (JAAR)

Jan 2016

\title{
Financial Status of Small Farmer Cooperative Limited (SFCL) in Surkhet District of Nepal
}

\author{
Liladhar Tiwari \\ Lecturer (Economics) \\ Midwestern University, Surkhet \\ liladhar70@gmail.com
}

\begin{abstract}
The present study has studied the status of Small Farmers Cooperative Limited (SFCL) in Surkhet District of Nepal. The cooperative movement originated from the philosophy of cooperation and later developed as a powerful tool to support to improve socio-economic status of resource poor, vulnerable, members of the lower cast people, women, labors and peasants. The Small Farmers Cooperative Limited functions with the guiding philosophy of group principle, self-help development and institutionalization of networks at the grassroots level to reduce the poverty. SFCL has three tier structures - village level groups, inter-groups and the main committee. This study applied a descriptive and analytical research design in the specific area. Study is based on both primary and secondary sources of data. The primary data are collected through observation and questionnaires and secondary data are collected from District Cooperative Office Surkhet (DCOS), Department of Cooperative (DoC), Central Bureau of Statistics (CBS), National Planning Commission (NPC), National Cooperative Federation of Nepal (NCF/N and so on. Some of the most remarkable contributions of these institutions are: saving collection, credit investment and socio-economic improvement. The SFCLs are guided by democratic norms and shares are issued to the members who are empowered with one member one vote for the general assembly purpose. The institutions function for socio-economic development with the strong policy of being apolitical and unbiased with no discrimination of any kind on religion and gender basis. The socio-economic status of cooperative members is changed through income generation. Similarly, in the comparison of expenditure increment before and after membership, an average expense is increased, result is highly significant.
\end{abstract}

KEY WORDS: Financial, Status, Economic Development, Small Farmer Cooperative Limited (SFCL)

\section{INTRODUCTION}

This study has focused to identifying the role of Small Farmer Cooperative in economic development. This study was undertaken in Surkhet district of Nepal. Cooperatives as the communitarian informal institutions have been traditionally embedded in the social and cultural 
traditions of Nepal. Guthis (religious trusts), Dharma Bhakaris (religious-oriented food grain stores), Parma (mutual labour exchange), etc; are a few instances. The formal genesis of the cooperative can be traced backed to April 2, 1956 with the foundation of Bakhanpur credit cooperative in Chitwan district. Later in 1959, Cooperative Societies Act (2016) was enacted. Despite the several revisions of the first cooperative societies Act, it was finally replaced by the Sajha societies Act in 1984. With the restoration of multiparty democracy in 1990, the Sajha societies Act was replaced again by the cooperatives Act in 1992 which has accepted the fundamental cooperative principles and created a legal base both for setting up the cooperative societies and translation of cooperative values, norms and principles into practice ( $\mathrm{NCF} / \mathrm{N}$, 2014). Cooperative sector contribute in GDP, approximately 3 percent and 20 percent contribute in financial sector. Cooperative sector is most important sector for economic development of Nepal (DoC, 2013).

Cooperative was initiated since the beginning of the $18^{\text {th }}$ century by Robert Owen (1771-1858) in England and Charles Fourier (1772-1837), Philippe J.B Bunchez (1796-1865) and Louis Blanc (1811-1882) in France had influenced development of the concept of modern cooperatives (Rhodes, 1995).

The International Cooperatives Alliance (ICA) was established in 1985. It made two formal declarations in cooperative principles in 1937 and 1966. Agricultural cooperative was initiated in the period from 1945 to 1960 and its network expended widely during 1960 to 1970 (Badal, 2004).

Asia and Africa applied cooperative strategies massively in agriculture and socio-economic development. After the end of cold war, globalization spread all over the world. Cooperatives are operating in such open market economy. They mobilize domestic financial resources by creating self-help organizations at the grassroots level around the world (Shrestha, 2006).

The word 'cooperative' is derived from the Latin word 'cooperari' that means working together with others. In the simple words, cooperation is a 'give and take' process, working together for similar and a common cause. For the long time in the history, cooperation remained in informal setting with different kinds of beings. Until around 200 years ago, people were living in the village communities, tribes and large extended families and even in the city where people felt at home and shared the problems and happiness. The cooperative movement originated from the philosophy of cooperation and later developed as a powerful tool to support to improve socioeconomic status of resource poor, vulnerable, members of the lower cast people, women, labors and peasants. Furthermore, cooperative promoted cohesiveness, mutual supports and congenial environment in the society. Cooperative principles have proved that small efforts of many people would make large contribution to socio-economic development of a society (Neupane, 2006).

The main goal of cooperative organizations is to improve socio-economic status of rural people by creating cooperation and mutual support among each other. Basic features of cooperatives are to organize community people into the groups, collect savings for the loan investment and social 
activities, share ideas on community social and economic development, empower grassroots, grasp financial resources, access technical assistance from the related other development agencies, develop self-operating financial institutions at the local/village level.

Cooperative strictly follows seven principles like voluntary and open membership, democratic process, financial contribution from members, freedom of autonomy and independence, education \& Regular training, cooperation among cooperatives and concern for community to promote and strengthen their institution to achieve the major goal of socio-economic development all over the world (Devekota, 2009).

\section{Small Farmers Cooperative Limited}

Agricultural Development Bank of Nepal had launched Small Farmers Development Program for two decades with the support of the Government of Nepal and Asian Development Bank for the upliftment of the small farmers. Small farmers were defined in terms of annual income less than NRs. 9000 and land holding less than 1 pakki bigha (two acres) in terai and around 12 ropani (nearly 600 sq. meters/ ropani) in mountain and hilly areas. Farmers groups were organized and the loan was disbursed in recommendation of the group and the chairperson was responsible for the preparation of group bonds. Small Farmers Cooperative was organized with the whole group members of the SFDP as members and the loan provided by the ADB/N was transferred to Small Farmers Cooperative Limited (Thakuri, 2010).

ADBL (1993) has helped publish the By-laws of the Small Farmers Cooperative Limited (SFCL) to provide basic rules and regulations of the cooperatives. General assembly is one of the most powerful authorities of SFCLs. It has full authority to prepare policies, procedure of SFCLs on the one hand and an approval of last year's expenditure and current year's program and budget on the other. Apart from this, it nominates auditor and finalizes staff salary for the current year. There must be at least 25 general members to be registered as a cooperative institution. General assembly is organized once a year at the end of fiscal year. General assembly elects the members of main committee including Chairperson, Vice-chairperson, Secretary, Treasurer and Members from among the general members. Management of SFCLs is guided and controlled by the main committee, so that certain accountabilities such as office management, accounting and loan management are handed-over to the staff of SFCLs. The main committee is fully accountable to loan investment, collection and enrollment of new members. Major functions of the main committee are loan investment, collection, and domestic resource mobilization, meeting organization, coordination, supervision, and follow-up and monitoring. In addition, executive committee could implement awareness development activities, empowerment development and community mobilization activities for development of their respective areas. Executive committee can be dissolved if majority of the general members approve the decision. Duration of executive committee and other sub-committees would be fixing by the general assembly. Generally, duration of committees is fixed at approximately three years. 
Main features of SFCLs are a multi-service co-operative at VDC level, three tier approaches at village, ward and VDC level, provides both financial and social services to its members, rural based program, members' ownership in both assets and liabilities and plan \& implements various projects as per the need of the members

This research studies the financial status of SFCLs in Surkhet District of Nepal. The study contributes to a great extent to exemplify the importance of cooperative sector for the economy. Small Farmers Cooperatives Limited (SFCL) lacks professional staff, do not have adequate training facilities and depend on fragile community development activities. No portfolio management, lack of effective business plan, inadequate mobilization of domestic resources, and lack of need-based financial programs are other major problems of rural cooperatives. Cooperatives have encountered problems of financial discipline, complexity in loan procedure, unavailability of sufficient fund and so far have failed to formulate appropriate legal system for defaulters.

Questions can be raised: Why access and utilization of saving and credit services are low in the rural area? The study will help to answer this question. The problem is also concentrated on how to mitigate the saving investing gap in the rural economy and how to provide universal access to finance. In this study, the financial status of the SFCLs in Surkhet District is explored.

\section{METHOD}

This study applied a descriptive and analytical research design in the specific area. For the study purpose, both quantitative and qualitative data are collected from the field. Purposive sampling technique was used to select the SFCL established by the different caste, areas, constituency of Surkhet district. Besides that, member of cooperatives were selected by using the lottery system of simple random sampling without replacement. Data was collected from the 170 members of sampled SFCLs. The present study primarily relies upon primary as well as secondary data. The cross section data was used in this study. Data collections have been carried out through the structured questionnaire. Instruments were self-reported semi-structured. All variables collected during the period of data collection have been measured systematically. Qualitative variables were coded and measured in nominal and ordinal scale according to the nature of variable. Quantitative variables were measured in ratio scale. All variables were entered in excel and they were analyzed systematically.

\section{RESULS AND DISCUSSION}

Small Farmers Cooperative Ltd (SFCL) is a multi-service cooperative designed to deliver primarily financial, but also non-financial services to its members in rural areas. SFCLs are civil society organizations, which pool their joint resources to meet basic needs and to defend their members' interests. They are member-owned and controlled and have an open membership policy towards "poor" farmers. 
SFCLs deliver various financial and non-financial services. Financial services include various forms of voluntary and compulsory savings products, a variety of loan products as well as a livestock insurance scheme. Non-financial services include construction of irrigation channels, establishment of milk collection centers, nursery programs and women empowerment programs.

\section{Organizational Structure and Progress of SFCLs}

SFCLs have the same general organizational structure as other financial institutions, i.e. a management body for daily business, a board of directors with a chairperson on the top as control organization and representatives of the member-owners. The annual General Assembly (GA) ensures that the ultimate control of the cooperative lies within its membership. SFCL is a three-tier organizational structure i.e. small farmers group at village level, inter-group in-ward level and a main committee in VDC level.

\section{General Assembly}

The General Assembly (GA) meets once a year after the end of the fiscal year. To conduct this meeting and to take decisions, at least 51 percent of members must be present; normally, actual attendance far exceeds this number. The major tasks of the GA are to approve the budget plan for the next year, exonerate the Management from the previous years' financial report, appoint an external auditor and present the auditors' report. In addition, the assembly discusses and decides upon new loan and savings policies, strategies for the expansion of SFCL's business plan, guidelines for the Main Committee and the distribution of profit. Furthermore, new board members and members of the Account and Supervision Committee are elected.

\section{Main Committee}

The Main Committee (MC) is, as the board of directors, the highest elected body in this memberbased organization. MC constitutes of representative of each inter-group. It is, as a steering committee, ultimately responsible for the SFCL's management. The Chairperson usually is a farmer with high prestige and a good reputation. The MC has the authority to delegate work responsibilities to staff members or the Inter-Group and Small Farmers Group representatives as it sees fit. MC-members do not get any remuneration for their work as long as the SFCL is not profitable. Later, allowances can be granted by the decision of the General Assembly on the basis of their commitment. Members are elected every two to three years. During monthly or need base MC meetings, they are asked whether they assume responsibility for loans given out in their respective Inter-Group.

\section{Inter-Groups}

Inter-Groups (IG) are composed of one representative of each Small Farmers (SF) Group. The Official positions in the Inter-Group are Chairperson, Vice-Chairperson, Secretary, Treasurer 
and Members. An Inter-Group member can be elected as representative in the Main Committee. These individuals play central roles as mediators between the Main Committee and SF-Groups. Positioned at a ward level, they co-ordinate community development and savings and loan activities. In cases of new members and formation of new groups, they check, verify and make recommendations to the Main Committee. Final decisions regarding provision of loans to members will in general practice be taken at the IG-level, even if the ultimate responsibility lies with the Main Committee. The Inter-Group also plays a very active role in the loan enforcement process.

\section{Small Farmers Groups}

Small farmers groups generally have the following structure: Cooperative members are headed by the Chairperson, Vice-Chairperson, Secretary, Treasurer and board members. The chairperson, convenes and chairs meetings, leads discussions and facilitates consensus building. The Secretary, mainly obligated to do the paperwork, and the Treasurer, who bears total responsibility for the group savings account, other members assist him. At the monthly meetings of these groups, a minimum number of members have to be present, but normally all members take part in the meeting. The meetings not only serve the purpose of deciding financial issues, but also make it possible to mutually exchange experiences on such issues as farming, sanitation or environment. The SF-Groups also organize social activities.

\section{Committees}

A very important sub-committee in the SFCL system is the Loan Sub-Committee, consisting of the Chairperson as coordinator, the Institutional Manager and the respective IG-Chairperson. This Sub-Committee plays a very crucial role in the rapid and flexible approval of loan demands. Another committee is the Account and Supervision Committee. Its members are elected by the General Assembly and are responsible for internal control. It checks the accounts on a quarterly basis, prepares the progress report for the Main Committee and makes the preliminary selection of the external auditor to be approved by the GA. Membership of this Committee consists of a Coordinator and two Assistants. The Coordinator must be a board member.

\section{Cooperatives of Surkhet District}

There were different categories of cooperatives registered under the Division of Cooperative Office, Surkhet. Some of them have been established with zero investment and some with large investment. According to the Statistics of Cooperative Enterprises (Department of Cooperative) 2013, altogether 533 cooperatives were formed in Surkhet. Among them, 154 were saving \& credit cooperatives, 117 were multipurpose cooperatives, 182 were agriculture, 22 were milk cooperative, 5 were consumer, 3 were electricity, 12 were herbal, 5 were communication, 31 were others and bee-farming $\&$ health cooperative with only one. 
Total contribution in national economy from Surkhet district of cooperatives was as NRs. 224 million share capital, NRs. 918 million saving deposit and direct employment to 527 people. The total investment was NRs. 1,039 million. Total membership had reached 80,152 of which 31,872 (40 percent) were male and 48,280 (60 percent) were female. Female membership participation rate was higher than the male membership (DoC, 2013).

\section{Small Farmers Cooperative Limited (SFCL) of Surkhet District}

According to the Statistics of Cooperative Enterprises (Department of Cooperative) 2013, total 182 Agriculture cooperatives were registered in Division Cooperative Office Surkhet. Small Farmers Cooperative Limited (SFCL) was registered agriculture cooperative. At present, 20 SFCLs was working in Surkhet district. Only two sample SFCLs were studied. These SFCLs were simply nine to nineteen years old cooperatives.

There were total of 1683 share members, of which 1162 were female and 521 were male from two selected sample cooperatives in the district. Of total 170 respondents, 142 were female and 28 were male. Female membership number was higher than the male membership. All respondents had taken membership of cooperative five years before. Only 10.10 percent share members were taken as sample unit while collecting the data. Each sampling unit from member of cooperatives was selected by lottery system of simple random sampling without replacement. That was done to prevent any form of biases.

\section{Status of Saving Deposit in Sampled SFCLs}

Saving deposit is the backbone of the SFCLs and it is expected that all members participate in this program. Through each monthly meeting, principally the members deposit their group saving in their accounts which is separately managed in the each group. Poor people in the villages have to depend on the moneylenders, friends and other informal financial institutions to get the money. Rural people have no other sources of financing during the emergency situation like accident, illness and natural calamities. People have very limited access to banks, finance companies and other credit investing institutions. Saving makes fund available for investment in income generating activities, emergency purposes and economic revitalization of the societies. Saving is one of the important components of SFCLs in which various saving schemes are offered by the institution to raise assets of the individual members and also increase the fund of the institution to invest in income generation activities for the cooperative members.

\section{Saving Deposit from SFCL, Mehelkuna}

SFCL Mehelkuna has been mobilizing domestic financial resources since its inception. Inaccessibility of adequate credit from formal financial institutions was a major factor affecting the development of socio-economic level of Mehelkuna. Considering prime importance of SFCL in the field of socio-economic improvement, Agricultural Development Bank Limited transferred 
Small Farmers Development Program into SFCL particularly for mobilizing domestic financial resources by the active participation of local people by themselves. However, SFCL could not achieve satisfactory result in saving collection program since the time while it was operated in the form of Small Farmers Development Program. The reason behind its ineffectiveness in saving collection as well as mobilization of that fund by the SFCL Mehelkuna was lack of adequate awareness campaigns, interaction workshop and also inadequate training conducted on saving collection and mobilization so far. Besides, members frequently visited different places of India for the seasonal employment purposes so that members were absent in monthly meeting and also failed to deposit their saving regularly in their group account. Members have been struggling to survive on limited resources such as unfertile land, very few livestock, and lack of surplus money and unavailability of other supporting activities.

Although, they encounter various economic problems in their daily lives, many people were saving money in their group accounts. Average total saving deposit reached to NRs. 3,880. Total sum of saving collection amount was NRs. 2,867,234 at the end of FY 2012/13. Interest rate on deposit provided 8 to 10 percent per annum. Overall scenario of saving deposit shows that interest of saving had very least risk and total amount of saving had maximum risk. Higher variation in saving deposit revealed in SFCL Mehelkuna due to the lack of regulation of savings from all group members, as a result, in any time saving deposit could be dropped.

Saving collection of SFCL revealed very negligible, because it collected average saving ranged between NRs. 25 to 110 per member per month. This amount of saving does not increase the fund of SFCL. Mehelkuna encountered many problems vulnerability, unemployment, food deficiency, illiteracy, deep-rooted beliefs, traditional values, norms, and lack of development facilities. Most of the people migrate to India seasonally for generating income to maintain their family livelihood. In this context, SFCL Mehelkuna had not been implementing effective saving activities to increase the fund for investment in economic and social development activities in order to improve their livelihood through generating employment opportunities.

\section{Saving Deposit from SFCL, Uttarganga}

SFCL, Uttarganga was recognized as one of the major cooperatives in the context of saving deposit as well as its mobilization in income generating activities in rural areas. To improve the income level of rural people, SFCL, Uttarganga had initiated saving schemes intensively by mobilizing domestic financial resources extensively. So far, after hand-over of Small Farmers Development Program (SFDP) into Small Farmers Cooperative Limited, saving mobilization had undertaken major priority from SFCL. In this connection, average saving deposit from SFCL Uttarganga and average total collection of saving per member reached NRs. 38,855. Total sum of saving collection amount was NRs. 36,679,293 in the end of FY 2012/13. Saving collection average ranged between NRs. 110 to 220 per member per month. Interest rate on deposit provided 9 to 11 percent per annum. Overall scenario of saving deposit shows that interest of 
saving had very least risk and if the saving amount has not been invested, total amount of saving has maximum risk. And also found higher risk in saving deposit due to the lack of regulation of their savings in their group account.

However, SFCL Uttarganga needs to focus on increasing saving amount in coming days. Ultimately, large quantity of saving amount helps to invest in income generating and social development activities in rural areas through cooperatives. Earnings from women led project were found more useful to invest in their children's education, family health treatment, family food and other social activities. It was also useful for the economic empowerment of women. Therefore, saving mobilizations from women need to increase in cooperatives largely and then overall development of cooperatives and members.

\section{Situation of Credit (Loan) Investment in Sampled SFCLs}

SFCL is one of the major microfinance models for the country. Its main aim is to collect savings from members in the village thereby investing it in income generating activities such as agricultural farming, livestock, business and cottage industry and other activities. In addition, it also provides loan for social activities such as health treatment, household expenditure, children education and so on.

To meet the major objective, it invests loan in short, medium and long-term basis in income generating activities to improve the livelihood of the rural people. Credit (Loan) investment is one of the major components of SFCL, in which, it invests loan to needy members who are recommended by group members and respective inter-groups. It has envisaged objective to provide loan to all the members who were involved in the groups.

\section{Loan Investment from SFCL, Mehelkuna}

Members of SFCL were comprised of poorest of the poor populace who do not have adequate income to fulfill their daily requirements. In order to increase economic status of rural population, SFCL had been investing credit to its members in income generating activities such agricultural farming, livestock, small business, cottage industry and so on. Moreover, SFCL categorizes their credit products into three components such as short-term, medium and long term. But most of the loan falls under the short-term category.

SFCL, Mehelkuna did not have adequate financial resources, owing to small savings of its members. In addition, it borrowed loan from Small Farmers Development Bank as a wholesale credit. Due to the unavailability of adequate fund for investment in various, most of the members borrowed loan for agricultural farming and small scale business for income generation. A large number of members have borrowed loan from SFCL. Loan investment from SFCL Mehelkuna, ranges from NRs. 6,000 to 225,000 with the nominal interest rate is 16 to 21 percent. Total loan investment amount was Sum of NRs. 7,138,786 up to FY 2012/13. Loan repayment status was also positively growing. 


\section{Loan Investment from SFCL, Uttarganga}

SFCL, Uttarganga does not have adequate financial resources, because of inadequate fund collected from savings from its members in the form of individual, group, children and old aged saving. In addition, it borrowed loan from Small Farmers Development Bank as a wholesale

credit. Due to the unavailability of adequate fund for investment in various activities, most of the members borrowed loan in single activities.

In SFCL Uttarganga, most of the members borrowed money for marketing, agro-business, nonagro-business and other purpose of income generation activities. The reasons behind the increase in demand of marketing loan are due to the accessibility of road facilities. Besides, Surkhet, a regional market center as well as district headquarters, which is densely populated lies very near to the SFCL area. It has good market potential to supply different goods basically daily essential. Next, agro-business was another important activity. Because, milk and dairy products had a high demand this area farmers were attached towards animal rearing.

A large number of members have borrowed loan from SFCL. Loan investment from SFCL, Uttarganga ranges from NRs. 5,000 to 500,000 with the nominal interest rate of 12 to 17 percent. Total loan investment amount was NRs. 52,336,906 up to FY 2012/13. Loan repayment status was also good. Members had paid principal and interest amount timely. Therefore, according to cooperative financial report, more than 80 percent loan had been repaid.

\section{Trend Analysis of Sampled SFCLs of Surkhet}

The study had assembled the operational data of two sampled SFCLs (Mehelkuna \& Uttarganga) for a period between Fiscal Year 2006/07 to 2012/13 (2063/064 to 2069/070 B.S) based on the availability of seven fiscal years of financial and Audit report. The analysis of trend of different aspects of their performance has been highlighted below.

\section{Trend Analysis of SFCL, Mehelkuna}

Total membership has reached 739 of which male membership was 486 and female membership was 253 up to 2014. The increment in share capital, saving and investment amount had been depicted in figure 1.

Figure 1 show that share capital is progressively increasing from initial phase to last FY 2012/13. Share capital was Rupees thirty three thousand in FY 2006/07 and it has increased in every year and in last FY 2012/13 share capital reached one million. Hence, people were involved in cooperative for economic activities.

Figure 1 Trend of Share Capital, Saving \& Investment of SFCL, Mehelkuna 


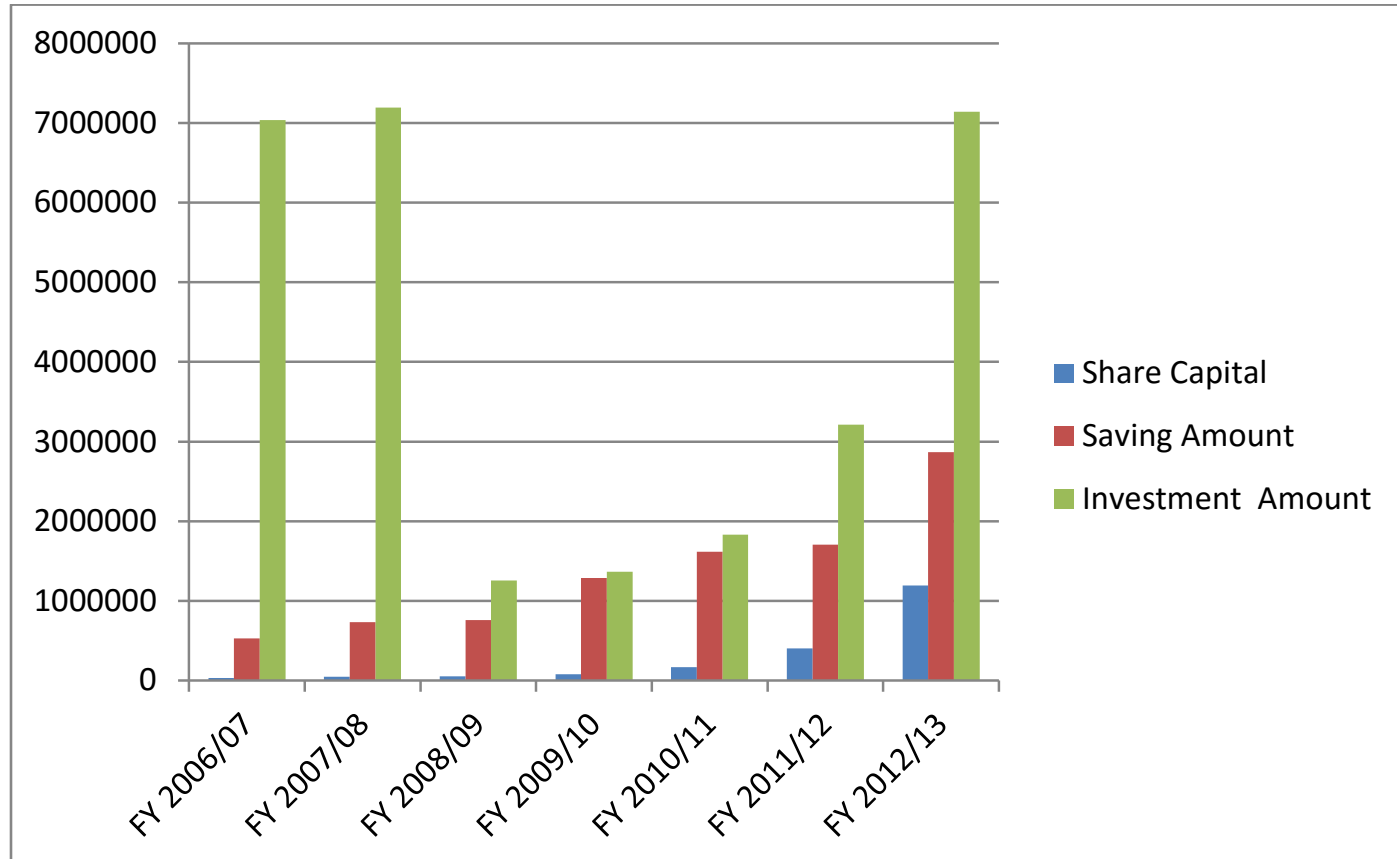

Source: Mehelkuna SFCL Different Year Annual Report

Savings has steadily increased from cooperative opening phase to last FY 2012/13. The members' saving was NRs. 5,31,000 in FY 2006/07 and it has increased every year. In the last FY 2012/13 saving amount reached NRs. 2.86 million. Therefore, people were attracted towards cooperative for financial activities to increase their living standard.

Figure 1 also indicates that investment amount was high in FY 2006/07 and FY 2007/08. The reason was previous due loan amount had not been settled in the end of these FY. But investment amount has been gradually increasing from FY 2008/09 to last FY 2012/13. The investment amount was NRs. 7 million in FY 2006/07 but it decreased in FY 2008/09 to NRs. 1 million. In the last FY 2012/13 investment amount increased to NRs. 7.13 million.

\section{Trend Analysis of SFCL, Uttarganga}

Total memberships have reached 944, of which male members were 35 and female members were 909 up to 2014. The growth in share capital, saving and investment amount had been described in figure 2 .

Figure 2 shows that share capital has been increasing from initial phase to last FY 2012/13. Share capital was NRs. 8,08,000 in FY 2006/07 and it increased every year and in the last FY 2012/13 share capital reached NRs. 7.8 million. Hence, people are involved in cooperative for security of future.

Figure 2 Trend of Share Capital, Saving \& Investment of SFCL, Uttarganga 


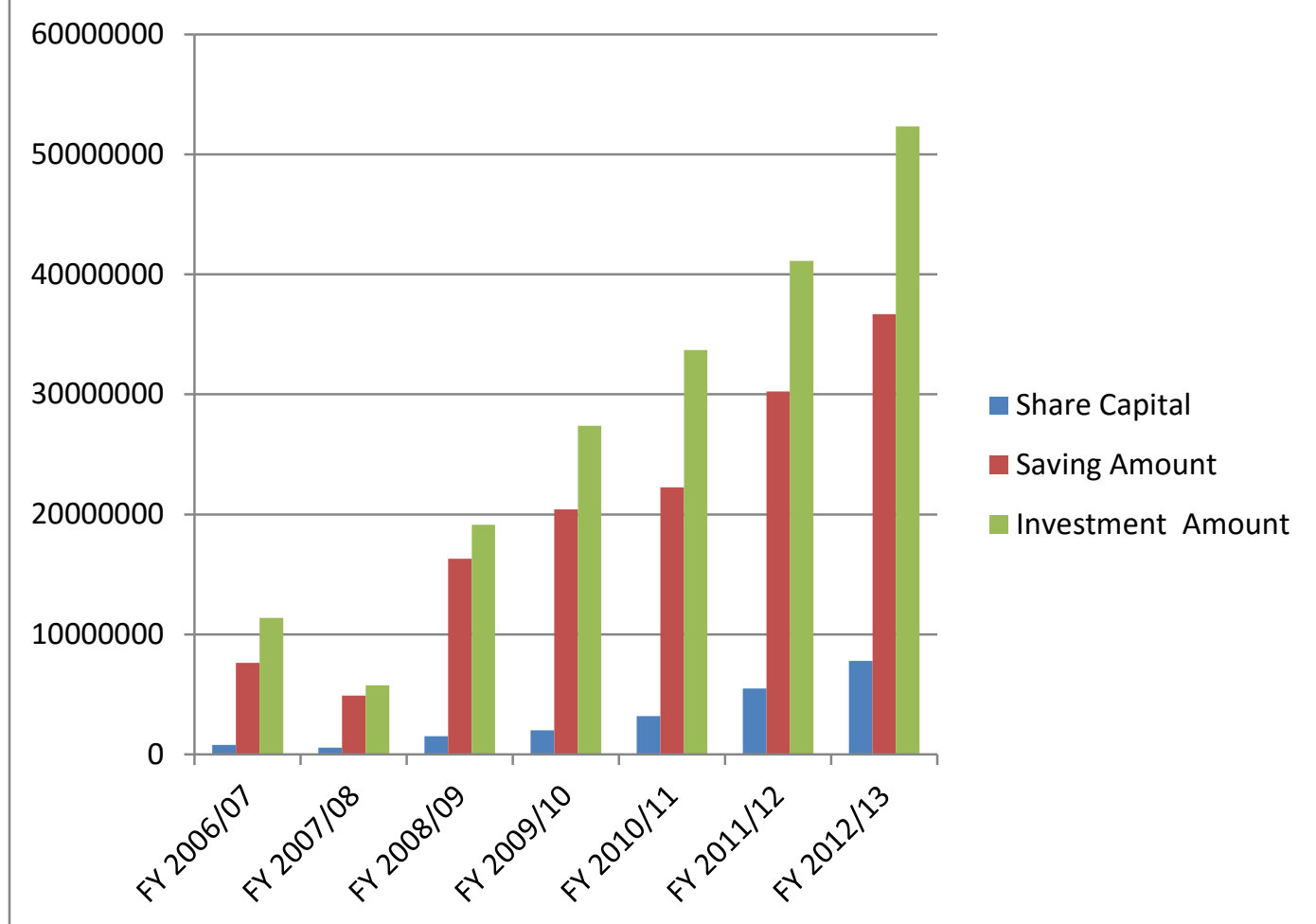

Source: Uttarganga SFCL Different Year Annual Report

Savings has gradually increased from starting of the cooperative till the last FY 2012/13. The members' saving was NRs. 7.6 million in FY 2006/07 and it increased rapidly in every year. In the last FY 2012/13 saving amount reached at NRs. 36.6 million. Therefore, the number of community people interested to join cooperative for saving and credit activities to change their lifestyle has substantially increased.

In addition, Figure 2 demonstrates that investment amount was NRs. 11.3 million in FY 2006/07 and it has rapidly increased every year. In the last FY 2012/13 investment amount increased to NRs. 52.3 million.

\section{CONCLUSION}

Direct employment had been given to four people in SFCL Mehelkuna and six people in SFCL Uttarganga. Indirectly many more cooperative members were benefited from Small Farmers Cooperatives. In Uttarganga, more than 96 percent members were female and they were totally holding and handling overall organization. But, in Mehelkuna, only 34 percent members were female in cooperative. Comparing both cooperatives, it was found that Women led management in SFCL Uttarganga was better than Mehelkuna SFCL. There were decentralized decisionmaking in SFCL management and accountability of its leader. There were three factors, namely; participation, transparency and accountability that endowed the SFCL with good governance internally. Gradually, it was also visible that the SFCLs are beginning to exert increasing 
influence in the functioning and decisions of local government bodies. In fact, there was close and crucial relationship between SFCLs and rural poor. Therefore, SFCLs' role was vital for economic development of rural area.

This study reveals that SFCLs have played a pivotal role in economic development. Due to lack of fulfillment of the duties and responsibilities of related sectors, the expected exponential result hadn't been achieved. On the basis of the close and deep study of two SFCLs of different parts of Surkhet district the concerned sectors accept the recommendation that by managing certain amount of funds for education and the cooperative members should be given vocational and skillful training for their occupations, awareness of empowerment and leadership development programs. The meeting of executive committee, auditing committee and other committee must be made effective and regular. Hence, SFCLs help a lot to reduce rural poverty. In a sense, the role of SFCLs is remarkable to improve poor quality of life. A great leap can be taken in income generation, if the values and norms of SFCLs are followed and applied from the professional approach.

\section{REFERENCES}

ADBL.(1993). By-laws of Small Farmers' Cooperative Limited. Kathmandu: Agricultural Development Bank Limited.

Badal, K. (2004). Sahakari- Siddanta ra Prayog. Kathmandu: Sahakari Sahayog Samuha.

CBS. (2011). Nepal Living Standard Survey-III 2010/011. Kathmandu: Central Bureau of Statistics.

Co-operative Act-2048 (1992), National Co-operative Development Board Act-2049(1993) and Co-operative Rules-2049 (1993). Kathmandu: Law Books Management Committee, Ministry of Law, justice and Parliamentary Affairs, Government of Nepal.

CTI.(2003). Business Cooperative Microfinance, Training Manual on Project Preparation and Appraisal. Kathmandu: ADBL.

DCOS.(2013). Sahakari Sambandhi Barsik Gatibidhi Pustikat. Surkhet: Division Cooperative Office, Surkhet.

Devkota, K. (2009). Institutional and Financial Sustainability of Small Farmers' Cooperative in the Hill of Nepal, A Ph.D. dissertation of Faculty of Humanities and Social Sciences. Kathmandu,Nepal: Tribhuvan University.

DOC. (2013). Statistics of Cooperative Enterprises. Kathmandu: Department of Cooperatives.

Kothari, C.R. (2004). Research Methodology. Methods \& Techniques, Second Edition. New Delhi: New Age International Publishers.

NCF/N.(2014). Concept Paper of First National Cooperative Congress. Kathmandu: Nepali Times, February 28. 
ISSN: 2362-1303 (Paper) | elSSN: 2362-1311(Online)

JOURNAL OF ADVANCED ACADEMIC RESEARCH (JAAR)

Jan 2016

Neupane, S. R. (2006). Cooperative Movement: A People based Development Approach, it's Role in the Economy of Nepal, unpublished Ph.D. thesis of Economics. New Delhi, India: Jamia Millia Islamia (Central University).

NPC. (2014). Nepal Human Development Report. National Planning Commission, Government of Nepal.

NPC. (2013). Thirteenth Three Year Plan (2070/071-2072/073). Kathmandu: National Planning Commission.

Rhodes, R. (1995). The International Cooperative Alliance During War and Peace 1910-1950, ICA, Geneva, Switzerland.

SFCL, Mehelkuna. (2013). Annual Reports. Surkhet: Small Farmers Cooperative Limited, Mehelkuna, Surkhet.

SFCL, Uttarganga. (2013). Annual Reports. Surkhet: Small Farmers Cooperative Limited, Uttarganga, Surkhet.

Shrestha, G. (2006). Yan Sangraha (Law Document), Part-II. Kathmandu: Paraibi Prakasan, M.House, Singhdarbar.

Thakuri, C. B. (2010). An Anatomy of Cooperative Movements in Nepal. Kathmandu, Nepal: Upkar Prakashan. 